\title{
Ballonnen boven de filosofische freesmachine ${ }^{1}$
}

\section{De publieksfilosoof als motivator en rolmodel}

\section{Sylvia Wenmackers}

In haar artikel onderzoekt Annemarie Kalis de vraag waarom publieksfilosofie een slechte naam heeft bij veel academische filosofen. In haar analyse gaat ze na welke doelen publieksfilosofie zou moeten vervullen. Op basis daarvan kunnen we kwaliteitscriteria bepalen, die verschillend kunnen zijn (en soms zelfs conflicterend) voor verschillende doelen. Een mogelijk antwoord op de uitgangsvraag is dat publieksfilosofie doorgaans doelen nastreeft die niet overeenstemmen met de criteria die critici hanteren. Verder doet Kalis een oproep om filosofie meer tot de wereld te richten.

Tijdens het lezen van het focusartikel viel het me op hoeveel overeenkomsten er zijn met publiekscommunicatie in de exacte wetenschappen - iets waar ik als wetenschapsfilosoof ook mijn steentje aan probeer bij te dragen. In deze reactie wil ik de analyse van Kalis aanvullen met een reflectie vanuit die context.

\section{(1) Communiceren om te motiveren}

Paige Brown Jarreau bevroeg meer dan 600 wetenschapsbloggers over welke rollen zij meenden te spelen. Er waren tien mogelijke antwoorden (waaronder 'publieke intellectueel', 'curator' en 'mediacriticus') en hierbij kwam 'explainer' als belangrijkste naar voren [Brown Jarreau 2015]. Het zou natuurlijk interessant zijn om te vergelijken met de rollen die publieksfilosofen zich aanmeten, maar helaas heb ik geen weet van gegevens hierover. Ook Kalis vermeldt het uitlegmodel als eerste optie, dus dit sluit alvast aan bij de bevinding van Brown Jarreau.

Toch denk ik dat er in beide artikels een belangrijk aspect ontbreekt. In mijn eigen communicatie met een breed publiek is het hoofddoel vaak motiveren: het eigen enthousiasme proberen overdragen, prikkelen en nieuwsgierig maken. Als een deel van mijn publiek achteraf op zoek gaat naar extra informatie, omdat ze denken "daar wil ik meer van weten" of "dat kan toch niet kloppen", dan is mijn opdracht geslaagd.

Om bij de analogie uit het originele artikel te blijven: stel je de opendeurdag voor bij de zagerij. Er worden vlaggetjes opgehangen, er is muziek en er zijn drankjes en versnaperingen. De bezoekers weten best dat er normaal geen ballonnen of ijsjes zijn, maar als het goed is, gaan ze toch naar huis met het gevoel: "het was leuk in de zagerij". Dit verlaagt de drempel om er terug te komen - als klant of toekomstige werknemer.

Een tweede doel of rol die in beide artikels lijkt te ontbreken is de functie als rolmodel - iets dat een publieksfilosoof zeker kan zijn. Hij of zij toont hoe filosofische vaardigheden en theorieën in een bepaalde context aangewend kunnen worden: dit hangt samen met het tweede en derde doel bij Kalis (vaardigheden trainen en materiaal aanreiken). Verder werkt een goed rolmodel ook inspirerend en dus motiverend.

Ooit volgde ik de academische lerarenopleiding (UGent): daar werd de "affectieve component van het leren" sterk benadrukt. Als studenten een goed gevoel krijgen in de les, dan zullen ze aandachtiger zijn, meer tijd besteden aan het vak en er dus ook meer van opsteken. Dit lijkt me een perfect argument om onderwerpen soms wel 'op te leuken'. Als dit ten koste gaat van de kwaliteit is

\footnotetext{
${ }^{1}$ Te verschijnen in Algemeen Nederlands Tijdschrift voor Wijsbegeerte, in reactie op een stuk van Annemarie Kalis, met als titel "Hoe zaagt men van dik hout planken?".
} 
er uiteraard een probleem, maar als er niemand wil luisteren naar je bijdrage, hoe kwalitatief hoogstaand die ook is, dan bereik je het uitlegdoel evenmin. Het komt er dus op neer de juiste balans te vinden.

Vanwege het motivatiedoel kijk ik veel minder streng naar filotainment dan Kalis blijkt te doen. Ik vind stand-up filosofie een interessante presentatievorm, die ik zelf overigens niet beheers. Wel maak ik soms gebruik van 'filmosofie': een film aangrijpen om een filosofisch idee uit te leggen. Hierbij is uitleggen dus alsnog een doel, maar motiveren gaat eraan vooraf. Zelfs een scheurkalender keur ik niet bij voorbaat af, omdat het informatie doseert en nieuwsgierigheid kan opwekken. Het klopt dat we de informatie door selectie en compressie vervormen, maar juist daarom is motivatie zo belangrijk: het zet iemand aan om, op een later moment, naar het hele verhaal te luisteren. (Om deze strategie te evalueren zouden we kunnen nagaan wat studenten die wijsbegeerte als minor of major kiezen hiertoe heeft aangezet.)

\section{(2) Huisfilosoof of hofnar?}

Kalis bespreekt de minachting voor publieksfilosofie door (andere) academische filosofen. Het eerste dat me hierbij opvalt is hoe wijdverspreid dit fenomeen is: ook in andere academische disciplines worden onderzoekers, die erin slagen helder met een breed publiek te communiceren, hier vaak door vakgenoten voor afgestraft. In de natuurwetenschappen heeft dit fenomeen zelfs een naam: het Sagan-effect.

\subsection{Eenvoud is niet simpel}

Van een gymnast, die op een belangrijke wedstrijd een topprestatie neerzet, wordt weleens gezegd dat hij of zij dat doet "alsof het geen enkele moeite kost". Als je zelf geen topsporter bent, weet je wel dat je zo'n prestatie niet kan evenaren, maar tegelijk lijkt het zo gemakkelijk dat je jezelf kan wijsmaken dat het jou met wat oefening ook zou lukken. Populaire sporters kunnen zo een positieve impact hebben op een hele generatie kinderen, die dezelfde sport willen beoefenen als dit rolmodel, maar bij volwassenen houden ze vooral illusies in stand.

Ook als een onderzoeker de kern van zijn of haar domein helder kan uitleggen, lijkt het heel eenvoudig. Ionica Smeets, hoogleraar in de wetenschapscommunicatie, formuleerde het in een bericht op Twitter als volgt [Smeets 2016]: "Steek je heel veel tijd in het bedenken hoe je iets moeilijks uitlegt, concludeert het publiek daarna dat je alleen simpele dingen vertelt." Nochtans maakt specialistische kennis het vaak lastig om een uitleg te geven die tegelijk accuraat is en toch toegankelijk is voor geïnteresseerde buitenstaanders. Deze taak vereist onder meer dat er geen jargon mag insluipen en ook dat veel details (die voor de specialist in kwestie vaak net het interessantste zijn) noodgedwongen onvermeld moeten blijven.

De specialist die voor een groot publiek spreekt, weet bovendien dat collega's het gekozen register te simplistisch zullen vinden en bepaalde lacunes zullen opmerken. Het gevaar dreigt dat deze collega's hierdoor een negatief beeld zullen krijgen - een gevaar dat des te groter is als die collega's zelf nooit spreken of schrijven voor niet-vakgenoten. (Bij een publiekslezing is dit overigens op te vangen door collega's ondertussen een opdracht te geven: laat ze nadenken over hoe zij dit onderwerp zouden uitleggen - een techniek die ik Smeets wel eens heb zien toepassen.) De onderzoeker in kwestie moet bovendien voortdurend ingaan tegen de eigen verinnerlijkte criticus, die bij academisch werk vaak wel nuttig werk levert.

\subsection{Het Sagan-effect}


Carl Sagan was een sterrenkundige die zeer populair was bij het Amerikaanse publiek door zijn rol als presentator van Cosmos, een TV-reeks uit 1980 over het heelal. Voordien schreef hij ook al populariserende artikels en boeken en in 1968 liep hij een vaste aanstelling mis bij zijn toenmalige universiteit, Harvard. Hierbij wordt aangenomen dat zijn populariserend werk in zijn nadeel heeft gespeeld (wat natuurlijk in individuele gevallen moeilijk te bewijzen valt). In het geval van Sagan wordt gesuggereerd dat zijn wetenschapspromotie door collega's vooral gezien werd als zelfpromotie en dat dit werd afgestraft [Morrison 2007].

Bepaalde mensen worden steeds opnieuw gevraagd voor mediabijdragen: eens het publiek hen kent en weet waaraan het zich kan verwachten, kan er sneller tot de kern van de zaak gekomen worden. Tegelijk is het juist op deze rol dat er kritiek dreigt van collega's, omdat zij weten dat de studiogast geen expert is in alle domeinen. Hierbij kan afgunst meespelen van collega's die relevantere expertise hebben, maar die zelf niet uitgenodigd zijn. De huisfilosoof dreigt dan als hofnar te worden afgeschilderd.

\section{(3) Eindbeschouwing}

Hoewel communicatie naar buiten gericht is, plukken we er - als individu en als discipline - ook zelf de vruchten van. Communiceren met een breed publiek verplicht ons om tot de essentie te komen van het thema waarover we werken. Dit kan soms confronterend zijn, maar ook verhelderend werken en zelfs inspireren tot vervolgonderzoek. Deze voordelen zijn er ook op bij academisch schrijven en doceren aan een universiteit, maar treden nog sterker op de voorgrond bij interactie met een breder publiek.

Overigens denk ik niet dat alle filosofie beoefend kan worden in een vorm die voor een groot publiek toegankelijk is. Voor sommige onderzoeksvragen is een diepgaande kennis van een corpus vereist, technische bagage en veel aandacht voor nuances - aspecten die niet passen binnen de bandbreedte van publiekscommunicatie.

Als we vaker naar buiten treden, hoeft er ook minder opgeleukt te worden. Als voor iedereen duidelijk is wat de meerwaarde kan zijn van een filosofische insteek in een debat, dan hoeft niet telkens opnieuw diezelfde horde genomen te worden. Zelf zou ik het beter vinden als er minder met huiswetenschappers of huisfilosofen gewerkt zou worden, zodat het publiek zou kunnen zien hoe divers en veelkleurig academici echt zijn. Maar tot we daar een goede oplossing voor gevonden hebben, hang ik zonder scrupules ballonnen op boven de filosofische freesmachine.

\section{Referenties}

[Jarreau 2015] Paige Brown Jarreau, "Science bloggers' self-perceived communication roles", JCOM 14 (2015) A02, pp. 1-25.

[Morrison 2007] David Morrison, "Carl Sagan's Life and Legacy as Scientist, Teacher, and Skeptic", Skeptical Inquirer 31.1, Jan./Feb. (2007) pp. 29-38.

[Smeets 2016] lonica Smeets, 2 maart 2016, URL: https://twitter.com/ionicasmeets/status/704972345254023168

Over de auteur - Sylvia Wenmackers (1980) is als onderzoeksprofessor verbonden aan het Centrum voor Logica en Analytische Wijsbegeerte (CLAW) van het Hoger Instituut voor Wijsbegeerte (HIW) van de KU Leuven (België). Ze studeerde theoretische natuurkunde (UGent, 2002) en behaalde een doctoraat in de fysica (UHasselt, 2008), alsook in de wetenschapsfilosofie (RU Groningen, 2011; cum laude). Haar belangrijkste academische publicaties gaan over infinitesimale kansen. Daarnaast schrijft ze blogs en columns voor Eos-magazine. 